\title{
Anatomia foliar de Eugenia florida DC. (Myrtaceae)
}

\author{
Ana Maria Donato ${ }^{*,}$, Berta Lange de Morretes $^{2}$ \\ 'Departamento de Biologia Vegetal, Universidade do Estado do Rio de Janeiro, Rua São Francisco Xavier 524, \\ 20550-013 Rio de Janeiro-RJ, Brasil \\ ${ }^{2}$ Departamento de Botânica, Instituto de Biociências, Universidade de São Paulo, Rua do Matão, \\ Travessa $14 n^{\circ}$ 321, Cidade Universitária, 05422-970 São Paulo, SP, Brasil
}

\begin{abstract}
RESUMO: Foi feito o estudo anatômico da folha de Eugenia florida DC., espécie arbórea da família Myrtaceae, coletada no Campus da Fundação Oswaldo Cruz, Rio de Janeiro, RJ. A espécie apresenta importantes propriedades farmacológicas, incluindo-se atividade antiviral. O presente estudo teve como objetivo fornecer dados, revelados através da microscopia óptica e da microscopia eletrônica de varredura, que possam contribuir para o conhecimento da espécie e, conseqüentemente, para a segurança em sua identificação. Anatomicamente, a folha é hipostomática, com organização dorsiventral do mesofilo. Apresenta tricomas simples apenas sobre a nervura mediana da face adaxial. As células epidérmicas apresentam contorno sinuoso em vista frontal e cutícula estriada. O parênquima paliçádico destaca-se pela grande quantidade de cristais prismáticos de oxalato de cálcio. Em posição subepidérmica ocorrem cavidades secretoras de óleos essenciais, pouco numerosas, nas duas faces da lâmina foliar. As células epidérmicas situadas sobre as estruturas secretoras constituem característica de valor diagnóstico e são reconhecíveis pela célula de topo, que é reniforme, circundada pelas adjacentes, que apresentam disposição radiada. A comparação entre folhas de sol e de sombra revela que, nas primeiras, as estruturas secretoras são completamente diferenciadas, ao contrário das folhas de sombra, além de apresentarem maior concentração de compostos ergásticos.
\end{abstract}

Unitermos: Eugenia florida, Myrtaceae, anatomia foliar, plantas medicinais, farmacobotânica.

\begin{abstract}
Foliar anatomy of Eugenia florida DC. (Myrtaceae)". A study of the foliar anatomy of Eugenia florida DC., a tree of Myrtaceae family collected at Fundação Oswaldo Cruz, Rio de Janeiro, RJ, was accomplished. This species presents important pharmacological properties, including antiviral activity. The aim of this research was to furnish data, revealed by optical microscopy and scanning electronically microscopy, in order to contribute to the knowledge of the species and to its safe identification. Anatomically, the leaf is hipostomatic, with dorsiventral mesophyll. Simple unicellular hairs are present only on the adaxial side of the leaf in the midvein region. Anticlinal walls of epidermal cells are undulate and the cuticle is striate. Palisade parenchyma presents a large amount of prismatic oxalate crystals. In subepidermical position there are secretory cavities bearing ethereal oils. These structures occur in a low frequency and are scattered along the both sides of the foliar blade. The epidermal cells that overlap the secretory cavities form an important characteristic anatomical feature. They are recognizable by the top cell, which presents a kidney shape surrounded by cells in a radiate way. The comparison between sun and shade leaves shows a complete development of the secretory cavities and a higher concentration of ergastic compounds in the first ones.
\end{abstract}

Keywords: Eugenia florida, Myrtaceae, foliar anatomy, medicinal plants, pharmacobotany.

\section{INTRODUÇÃO}

A importância dos produtos naturais na formulação dos medicamentos é evidenciada quando se considera que, mesmo nos países industrializados, $45 \%$ dos produtos farmacêuticos provêm de produtos naturais (Castro et al., 2004). O estudo de plantas medicinais, sob o ponto de vista anatômico, revela-se de grande interesse, pois contribui para o controle de qualidade e a correta identificação de fármacos vegetais (Duarte \& Menarim, 2006; Leite et al., 2007; Marques et al., 2007; Scopel et al., 2007; Mauro et al., 2008; Carpano et al., 2009; Gomes et al., 2009). Eugenia florida DC. pertence à família Myrtaceae, a qual compreende cerca de 3500 espécies agrupadas em, aproximadamente, 100 gêneros, com distribuição predominantemente na América tropical e na Austrália (Barroso et al., 1984). Essa família é considerada de grande importância ecológica, tanto na Mata Atlântica 
(Barroso \& Perón, 1994; Mori et al., 1983) como na composição das Restingas (Araújo \& Henriques, 1984), além de ter inúmeras espécies com propriedades medicinais (Agra et al., 2007; 2008; Veiga-Junior, 2008; Leitão et al., 2009). Seus representantes são constituídos por árvores ou arbustos com folhas simples, geralmente opostas, com margens inteiras, caracteristicamente providas de glândulas oleíferas, produtoras de óleos essenciais (Apel et al., 2006). Menezes-de-Lima Jr. et al. (1997), estudando essa família, detectaram atividade antiinflamatória relevante, em várias de suas espécies, atribuindo este efeito à presença dos sesquiterpenos de seus óleos essenciais. Siani \& Branquinho (1997) referem que parte do arsenal químico de defesa das plantas contra predadores herbívoros e microorganismos, é representada pelos óleos essenciais. As folhas de Eugenia florida encerram ácidos triterpênicos (betulínico e platânico), os quais apresentam atividade contra o HIV (Siani et al., 1998a,b). Junges et al. (1999) detectaram, nessa espécie, vários triterpenos, os quais constituem um grande grupo de produtos naturais, farmacologicamente ativos, com um amplo espectro de atividades biológicas, inclusive antiviral.

Este trabalho teve por objetivo caracterizar, anatomicamente, as folhas de E. florida, registrando-se, também, as diferenças estruturais observadas entre folhas de sol (da periferia da copa) e folhas de sombra (do interior da copa).

\section{MATERIAL E MÉTODOS}

O material estudado é proveniente de exemplares localizados no Campus da Fundação Oswaldo Cruz, situado na Rua Sizenando Nabuco, $\mathrm{n}^{\circ} 100$, Manguinhos, Rio de Janeiro, RJ. O local, originariamente, um mangue, foi aterrado e urbanizado, mantendo, entretanto, parte de sua vegetação original, com muitos representantes arbóreos, entre os quais, alguns indivíduos de E. florida, os quais vivem em ambiente relativamente sombreado, devido à presença de árvores de maior porte nas adjacências. A relativa densidade de sua copa motivou o estudo anatômico comparativo entre folhas situadas mais externamente, expostas à uma maior intensidade luminosa, as quais foram chamadas "folhas de sol", e folhas localizadas mais internamente, as quais foram denominadas "folhas de sombra", registrando-se as diferenças encontradas. Foram confeccionadas exsicatas, as quais se encontram depositadas no Herbário da Universidade de São Paulo, USP, com o número de registro: SPF 155.530 e no Herbário da Universidade do Estado do Rio de Janeiro, UERJ, com o registro HRJ 9.941.

O material foi fixado em FAA, com graduação alcoólica de $70^{\circ} \mathrm{GL}$, por $48 \mathrm{~h}$, sendo estocado, posteriormente, em etanol $70^{\circ}$ GL (Johansen, 1940). Para a determinação da forma do limbo foliar, comparou-se o material estudado com os padrões apresentados por Oliveira \& Akissue (1989). As lâminas semipermanentes foram confeccionadas a partir de cortes obtidos à mão livre. A coloração das secções transversais da lâmina foliar e do pecíolo em seu terço médio, foi feita com solução de azul de astra e safranina, ambas a 1\%, em água, na proporção de 9:1 (Bukatsch, 1972).

As epidermes foram dissociadas pelo método de Jeffrey e coradas com safranina aquosa e hidroalcólica (Johansen, l.c.). A diafanização e a coloração de folhas inteiras foram realizadas, segundo a técnica de Foster (1949) e o padrão de venação foliar foi determinado de acordo com a classificação de Hickey (1979). Para calcular a freqüência média das estruturas secretoras subepidérmicas, foram examinados 25 campos ópticos de secções paradérmicas adjacentes à epiderme das faces adaxial e abaxial das folhas, realizando-se a contagem e o cálculo da média aritmética. $\mathrm{O}$ mesmo procedimento foi utilizado para a contagem dos estômatos. Os dados foram comparados estatisticamente, utilizando-se o teste $t$ de Student (Vieira, 1983), estabelecendo-se o nível de significância de $5 \%$.

Secções histológicas obtidas de material fresco foram submetidas a testes histoquímicos. Grãos de amido, taninos e lipídios foram identificados pelo emprego, respectivamente, de lugol, solução de sais de ferro e Sudan IV (Johansen, 1940). Glicídios redutores foram localizados com o reagente de Benedict (McLean; Ivimey Cook, 1958). A natureza química dos cristais foi analisada através de sua solubilidade em ácidos (Howarth; Warne, 1959). O teste para lignina foi efetuado com floroglucina e ácido hidroclórico (Johansen, l.c.). Para evidenciar antocianinas, o material foi submetido a vapores de amônia (Johansen, l.c.).

O registro fotográfico foi feito com microscópio óptico Carl Zeiss Jena, acoplado à máquina fotográfica. Para as medidas das estruturas anatômicas foi utilizada uma ocular micrométrica devidamente aferida com lâmina contendo escala micrométrica. Os esquemas foram confeccionados com o auxílio de microscópio estereoscópico Zeiss, modelo Stemi SV6, equipado com câmara clara. Para exame ao microscópio eletrônico de varredura (MEV), fragmentos de folhas foram desidratados e submetidos à série etanólica ascendente. Em seguida, foram levados ao ponto crítico, utilizando-se o secador CPD-30, sendo, então, metalizados com ouro e levados ao MEV para observação e registro fotográfico.

\section{RESULTADOS}

\section{Morfologia}

E. florida é uma pequena árvore, com aproximadamente $3,5 \mathrm{~m}$ de altura, floresce em outubro e frutifica desde fins de novembro até meados de dezembro (Figuras 1a, 1b). Seus frutos são comestíveis e muito saborosos.

A folha de E. florida é simples, oblongo- 
lanceolada, de margem inteira, com textura cartácea, base simétrica e ápice suavemente acuminado (Figuras 1 e 2). O limbo mede de 9 a $13,5 \mathrm{~cm}$ de comprimento, por 4,5 a $6 \mathrm{~cm}$ de largura. O pecíolo mede de 6 a $9 \mathrm{~mm}$ de comprimento por $1 \mathrm{a} 1,5 \mathrm{~mm}$ de diâmetro na base. As maiores dimensões referem-se às folhas de sombra e as menores, às folhas de sol. Em estado natural, a folha é verde nas duas faces, apresentando-se um pouco mais clara no lado abaxial. Quando jovem, a folha é tênue, flexível e de coloração vinho, devido à presença de antocianina. $\mathrm{O}$ padrão de venação é do tipo camptódromo-broquidódromo (Figura 2a). Comparando-se a venação das folhas de sol e de sombra, constata-se maior densidade vascular nas primeiras (Figuras 2b, 2c).

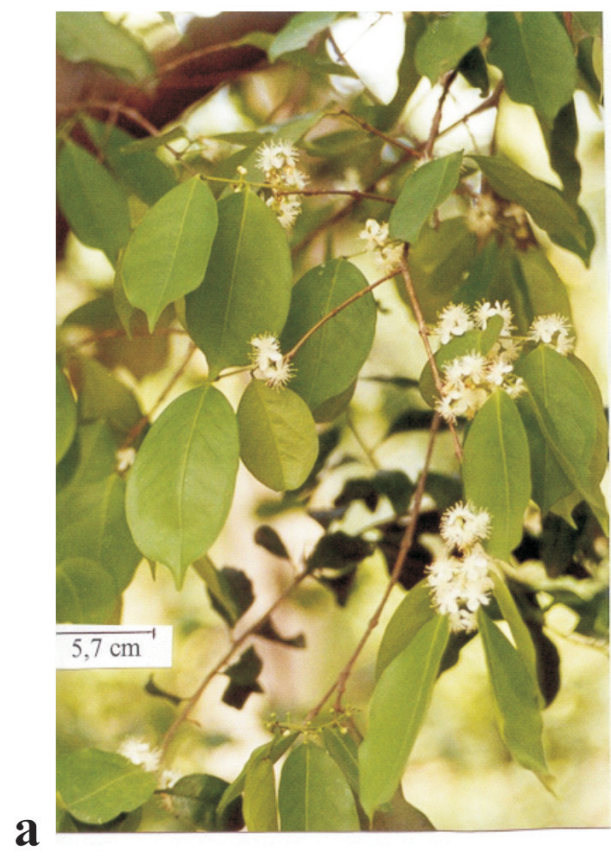

Figura 1. Eugenia florida em flor (a) e com frutos (b).
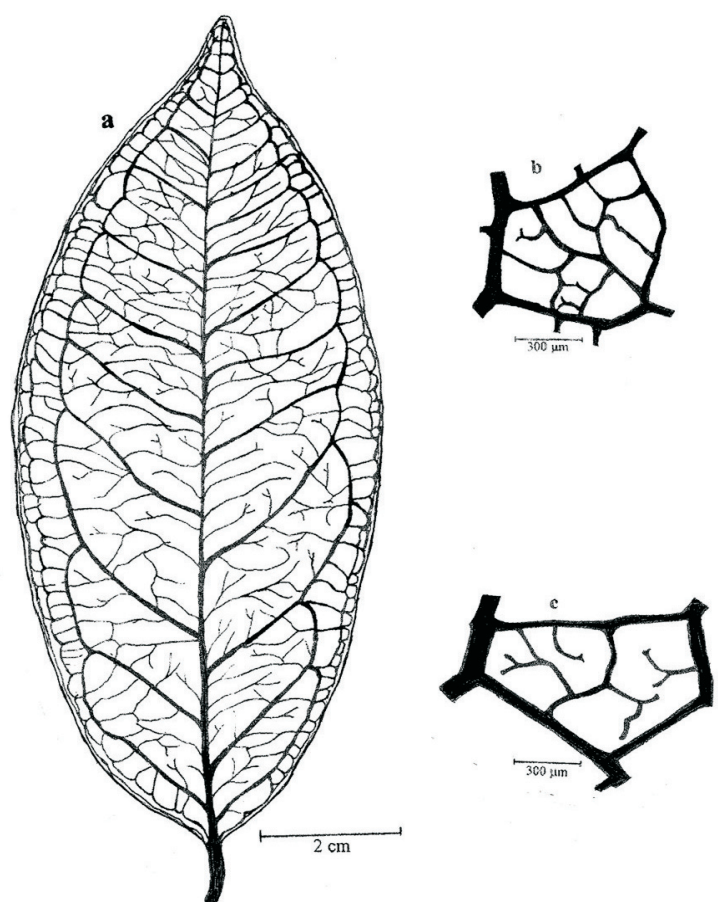

Figura 2. a, Venação de Eugenia florida do tipo camptódromobroquidódromo; b, Pormenor de aréola e terminações de nervuras, em folha de sol; c, Aréola de folha de sombra. - Note-se a maior densidade vascular na aréola de folha de sol.

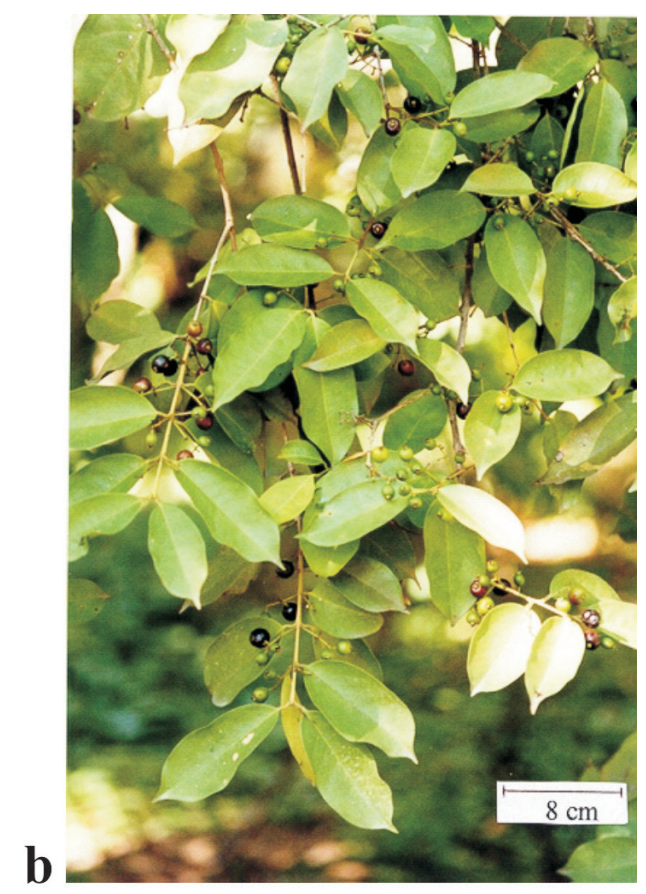

\section{Descrição anatômica}

\section{Sistema de revestimento}

A epiderme da face adaxial da folha de E. florida revela, em vista frontal, células com paredes anticlinais sinuosas e cutícula com estrias, sendo estas mais acentuadas em folhas de sol, quando comparadas com folhas de sombra (Figuras 3a, 3b). $\mathrm{O}$ aspecto das estrias em microscopia eletrônica de varredura pode ser visto na Figuras $4 \mathrm{a}$ e $4 \mathrm{~b}$. Nas regiões sobre as nervuras, as células são alongadas, pouco onduladas ou retas e com disposição paralela. $\mathrm{Na}$ região da nervura mediana ocorrem tricomas simples, unicelulares (Figura 5a). No restante da lâmina foliar, é freqüente a ocorrência de cicatrizes de tricomas (Figura $5 b)$. As células epidérmicas situadas sobre as estruturas secretoras de óleos essenciais são facilmente reconhecíveis pela presença de uma célula reniforme incolor, ao redor da qual, as células adjacentes dispõem-se de forma radiada (Figura 5b). Em secção transversal, a epiderme adaxial revela-se uniestratificada, com espessamento da cutícula e da parede periclinal externa, característica esta que se apresenta mais acentuada nas folhas de sol (Figuras 6a, 6b). Pequenas projeções das paredes periclinais externas, em direção ao lume celular, podem ser observadas nas 
células epidérmicas (Figuras 6a, 6b).

A epiderme da face abaxial da folha de E. florida assemelha-se à da face adaxial, apresentando, entretanto, dimensões um pouco menores e as estrias cuticulares atenuadas. Apresenta, ainda, estômatos do tipo paracítico (Figuras 7a, 7b) com freqüência média de 392 por $\mathrm{mm}^{2}$ nas folhas de sol e de 297 por $\mathrm{mm}^{2}$ nas folhas de sombra. A comparação estatística das médias encontradas, a qual permite afirmar que a densidade estomática das folhas de sol é maior do que a outra encontra-se na Tabela 1. Em

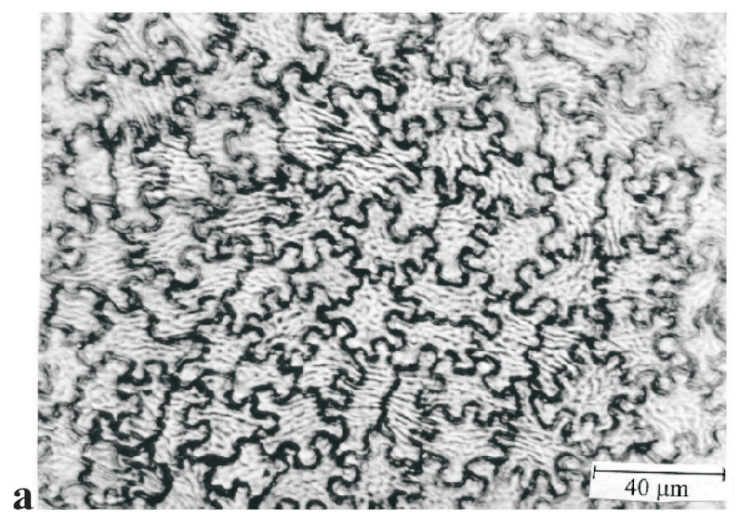

secção transversal da lâmina foliar, os estômatos mostramse situados no mesmo nível que os demais elementos epidérmicos (Figura 8). Raros tricomas unicelulares podem ser encontrados nesta face da lâmina foliar (Figura 7a). As células epidérmicas situadas sobre as estruturas secretoras são semelhantes às já descritas para a epiderme adaxial.

Os testes histoquímicos revelaram a presença de taninos, açúcares e lipídios em algumas células epidérmicas das duas faces da lâmina foliar.

Figura 3. Epiderme adaxial da folha Eugenia florida, em vista frontal. a, Folha de sombra; b, Folha de sol, evidenciando as estrias cuticulares mais acentuadas em relação à anterior e, no centro da foto, destaca-se a célula reniforme incolor, situada sobre a cavidade secretora subepidérmica.
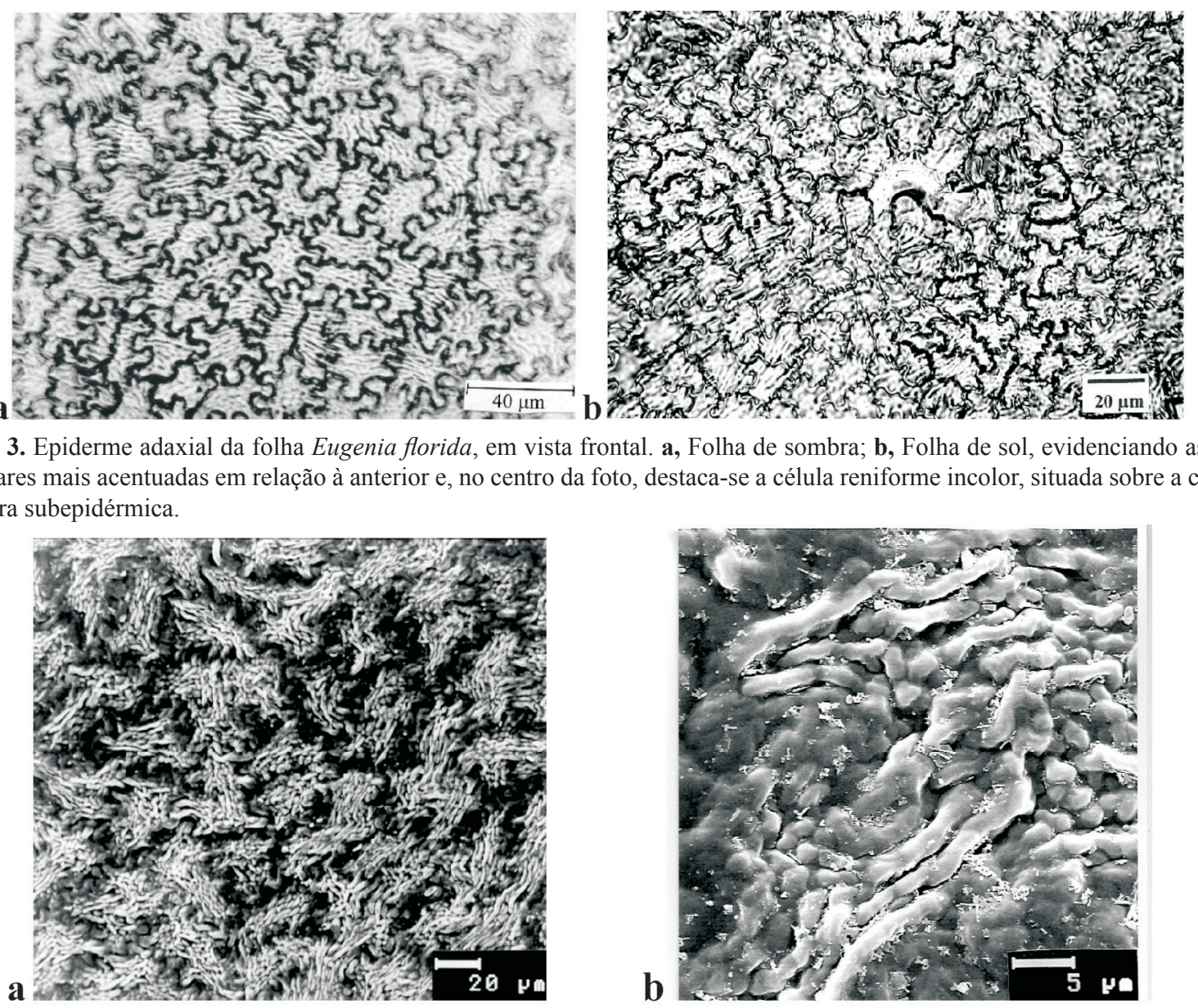

Figura 4. a, Estrias cuticulares da face adaxial de Eugenia florida (folha de sol), em microscopia eletrônica de varredura; b, Pormenor das estrias.
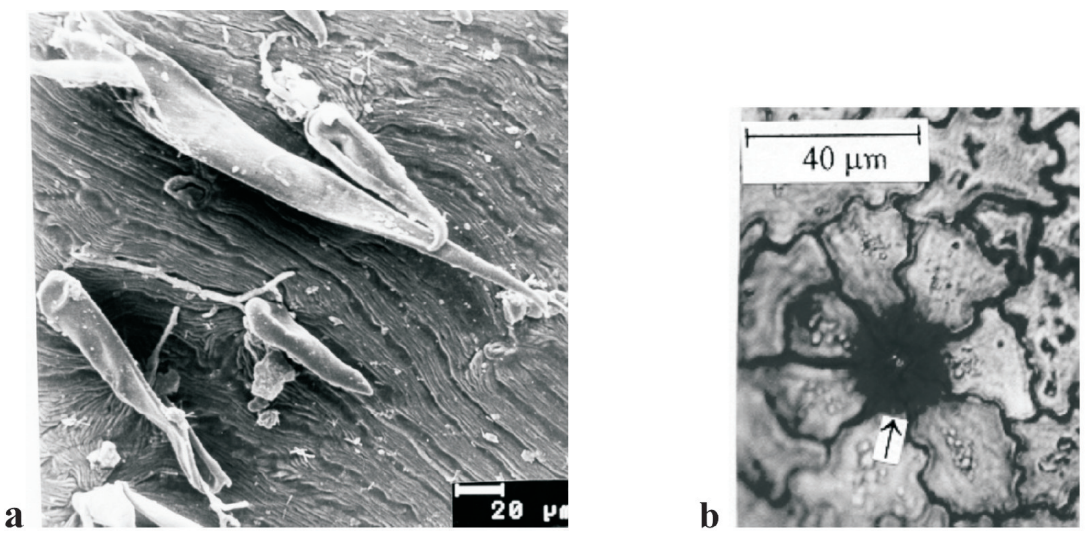

Figura 5. a, Vista frontal da epiderme adaxial da folha de Eugenia florida, na região da nervura mediana, em microscopia eletrônica de varredura; $\mathbf{b}$, Cicatriz de pêlo (seta). 

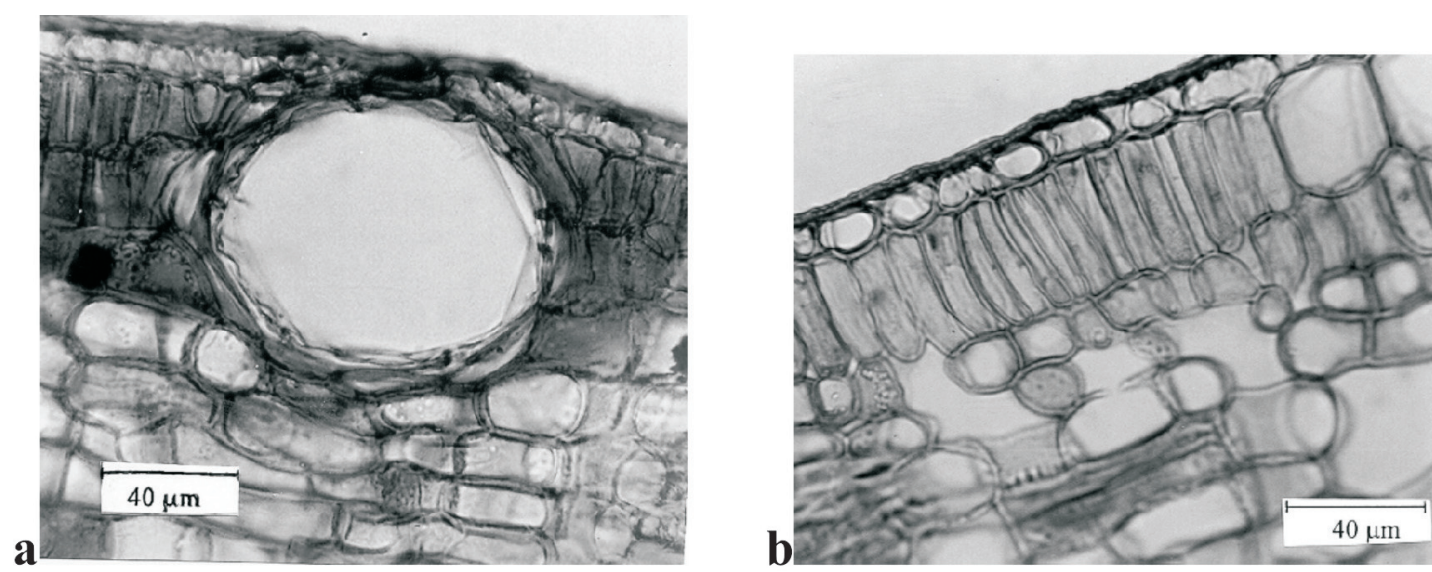

Figura 6. a, Secção transversal da lâmina foliar de Eugenia florida, na região da face adaxial (folha de sol), evidenciando-se as células epidérmicas e uma cavidade secretora subepidérmica; b, Idem (folha de sombra). Note-se que a região da cavidade secretora (no alto, à direita) encontra-se incompletamente diferenciada.
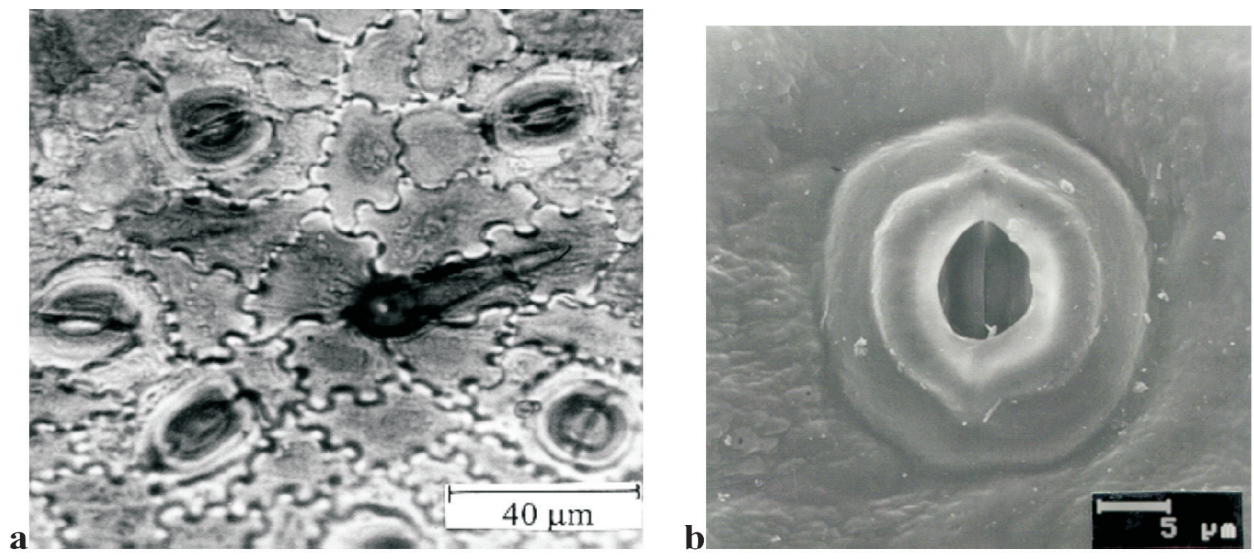

Figura 7. a, Vista frontal da epiderme abaxial de Eugenia florida, exibindo as células com paredes anticlinais sinuosas, estômatos paracíticos e um raro pêlo simples unicelular; b, Pormenor de um estômato em microscopia eletrônica de varredura.

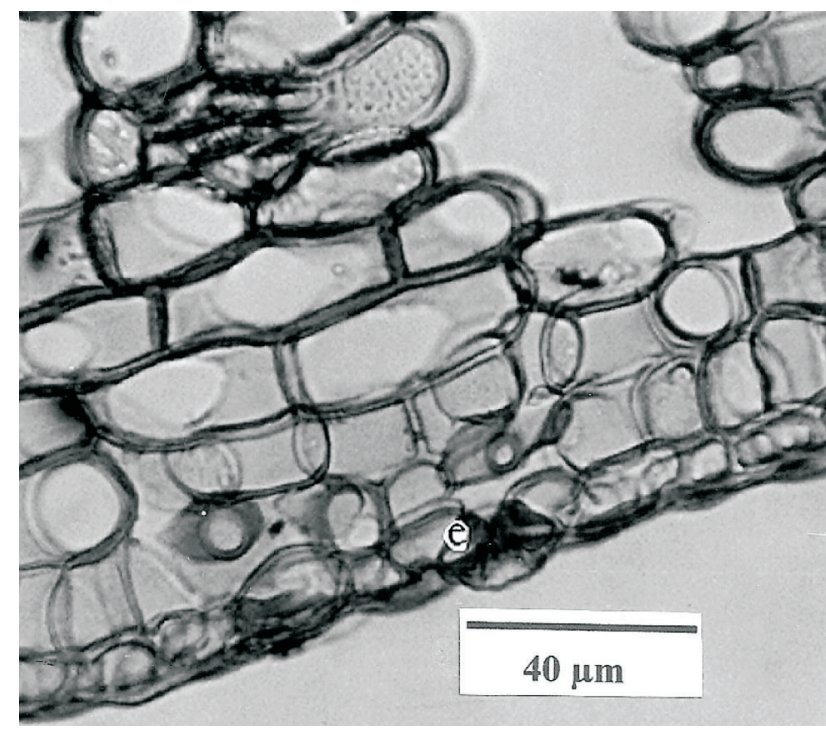

Figura 8. Pormenor da epiderme abaxial de Eugenia florida, evidenciando um estômato (e) nivelado com as demais células. Folha de sombra.
Tabela 1. Densidade de estômatos em área foliar equivalente a $0,015 \mathrm{~mm}^{2}$ (área do campo óptico do microscópio) de Eugenia florida. Com o nível de significância igual a 5\%, o teste $t$ revela que a densidade de estômatos nas folhas de sol é maior do que nas de sombra.

\begin{tabular}{|l|c|c|c|}
\hline Eugenia florida & $n$ & $x_{-}$ & $s^{2}$ \\
\hline Folhas de sol & 25 & 6 & 2,43 \\
\hline Folhas de sombra & 25 & 4,5 & 2,08 \\
\hline
\end{tabular}

$n=$ tamanho da amostra; $x$ = média; $s^{2}=$ variância.

\section{Lâmina foliar}

A secção transversal da lâmina foliar de E. florida revela estrutura tipicamente dorsiventral. O parênquima paliçádico mostra-se organizado em um ou dois estratos, conforme a folha tenha se desenvolvido em maior ou menor luminosidade, respectivamente (Figuras 9a, 9b). Outras diferenças anatômicas constatadas entre as folhas de sol e de sombra, no que se refere ao mesofilo, são a espessura da lâmina foliar e a compactação das células, que são maiores nas folhas de sol (Figuras 9a, 9b). Nestas, a espessura média do mesofilo corresponde a cerca de 
$240 \mu \mathrm{m}$, e nas de sombra, $175 \mu \mathrm{m}$. São numerosos os idioblastos contendo cristais prismáticos de oxalato de cálcio no parênquima paliçádico (Figuras 10a, 10b). Em luz polarizada, esses cristais revelam-se anisotrópicos e são mais numerosos nas folhas de sol. Cavidades secretoras, de secção arredondada, situadas imediatamente abaixo da epiderme, também ocorrem, intercaladas, neste parênquima (Figura 11a), porém em quantidade menor do que os idioblastos cristalíferos. As estruturas secretoras mais desenvolvidas apresentam um diâmetro que ultrapassa a altura das células do parênquima paliçádico. Seu epitélio secretor é constituído por células achatadas, com paredes delgadas (Figura 6a). O material contido no interior dessas cavidades secretoras reage positivamente aos testes de lipídios, açúcares e taninos. Nas folhas de sombra, na mesma posição ocupada pelas cavidades secretoras nas folhas de sol, ocorrem estruturas volumosas que, no entanto, não apresentam epitélio secretor, aparentando serem cavidades secretoras incompletamente diferenciadas (Figuras 6b, 9b). Segue-se o parênquima lacunoso com 8 a 10 estratos de células, as quais delimitam amplos espaços intercelulares nas folhas de sombra, mostrando-se mais compactadas nas folhas de sol (Figuras 9a, 9b). Neste parênquima ocorrem raros idioblastos contendo drusas de oxalato de cálcio (Figura 11a). A conexão entre o parênquima paliçádico e o lacunoso é feita através de um estrato de células coletoras (Figura 10a), observando-se duas ou mais células da paliçada posicionadas sobre uma célula coletora. No parênquima lacunoso, situam-se os feixes vasculares, envolvidos por uma bainha parenquimática, a qual pode conter cloroplastos nas folhas de sombra (Fig ura 11b). Nos dois pólos do feixe ocorrem fibras esclerenquimáticas. Os feixes de menor calibre são do tipo colateral, enquanto os mais desenvolvidos apresentam floema também no pólo adaxial do xilema, caracterizando-se como feixes vasculares bicolaterais. Adjacentes à epiderme abaxial, de modo semelhante ao que ocorre na adaxial, encontramse estruturas secretoras distribuídas de modo rarefeito. Nas folhas de sol, a média dessas estruturas é de 4 por $\mathrm{mm}^{2}$, enquanto nas de sombra a média é de 2 por $\mathrm{mm}^{2}$. Na Tabela 2 encontram-se sintetizadas as principais diferenças anatômicas entre as folhas de sol e de sombra de $E$. florida. Nos testes histoquímicos foi possível constatar a presença de glicídios no parênquima paliçádico, em alguns elementos do lacunoso e no floema. A presença de lipídios, na forma de gotículas, foi observada em algumas células do mesofilo e no interior das cavidades secretoras.

A região do bordo foliar é ligeiramente fletida em direção à face abaxial, nas folhas de sombra e retilínea nas folhas de sol (Figuras 12a, 12b). O parênquima paliçádico mostra-se interrompido na região distal do bordo e o número de estratos celulares do parênquima lacunoso reduz-se a cerca de cinco. Esta região é constituída por um colênquima que apresenta espessamento parietal homogêneo e apresenta-se mais desenvolvido nas folhas de sol (Figuras 12a, 12b). Próximo à região distal do bordo, ocorre um feixe vascular, com reduzido número de elementos condutores e numerosas fibras. Nas folhas de sol observa-se que, além do feixe vascular, ocorre um cordão de fibras esclerenquimáticas situado externamente àquele (Figura 12a). Cavidades secretoras podem estar presentes na região do bordo foliar (Figura 12a).

A região da nervura mediana, em secção transversal, apresenta-se plano-convexa (Figura 13a). O parênquima paliçádico é interrompido nesta região, sendo substituído por células colenquimáticas (Figura 14a). O estrato celular mais interno do colênquima faz contato com as fibras esclerenquimáticas situadas na periferia do floema (Figuras 13a, 13b). Este situa-se nos dois pólos do xilema, caracterizando o sistema vascular como bicolateral (Figuras 13a, 13b). O xilema ocupa a região central da nervura e encontra-se organizado em um arco, com a abertura voltada para a face adaxial da lâmina foliar. Os elementos traqueais organizam-se em fileiras intercaladas com raios parenquimáticos. O floema externo, isto é, o da região abaxial, também se mostra guarnecido por fibras esclerenquimáticas. Entre essas fibras e a epiderme abaxial ocorrem, geralmente, oito estratos de colênquima com as paredes celulósicas espessadas homogeneamente. Algumas dessas células apresentam cristais de oxalato de cálcio (Figura 14b). Nos testes histoquímicos constatou-se, além dos resultados já descritos para o restante da lâmina foliar, a presença de taninos nos raios parenquimáticos do sistema vascular e no colênquima.

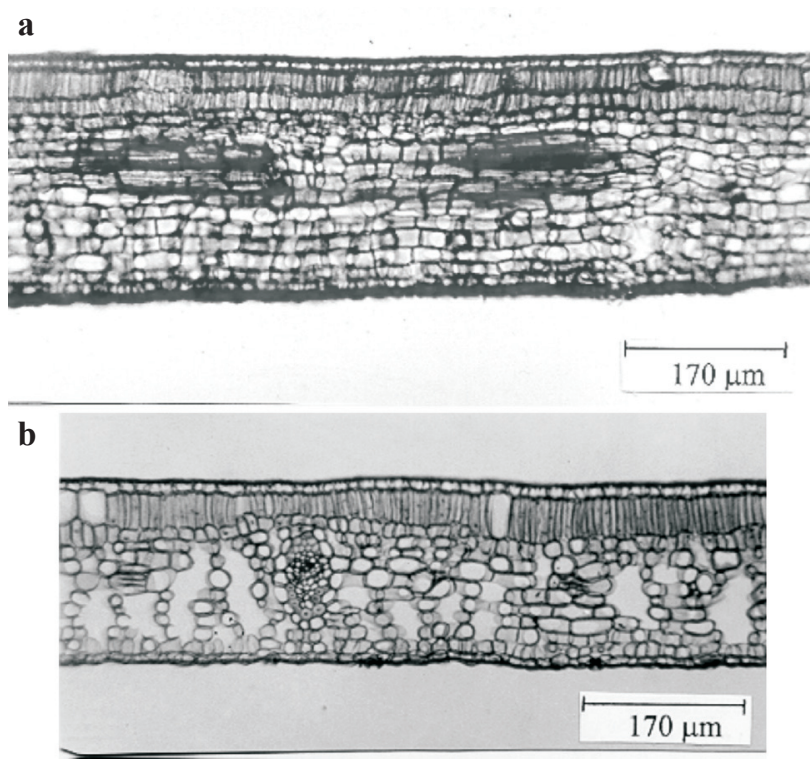

Figura 9. Secção transversal da lâmina foliar de Eugenia florida. a, Folha de sol; b, Folha de sombra. 

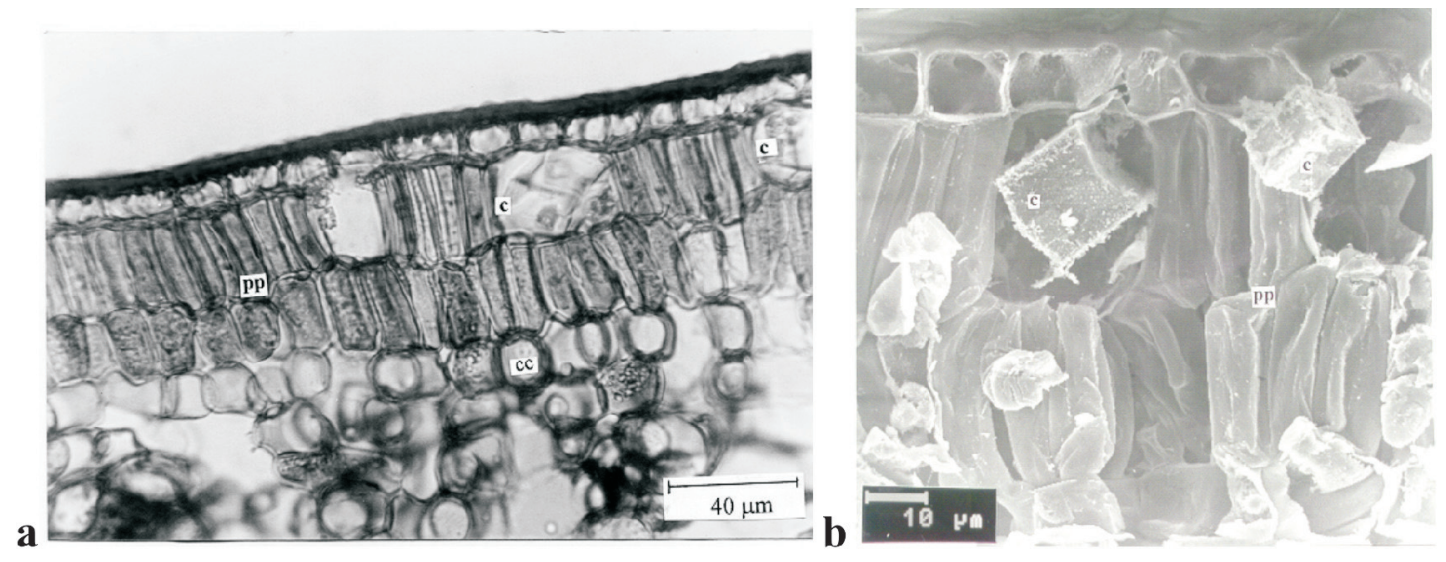

Figura 10. Pormenor da porção adaxial da lâmina foliar de Eugenia florida, em secção transversal. a, Em microscopia óptica, evidenciando os cristais prismáticos (c) no parênquima paliçádico (pp) e célula coletora (cc); b, Observa-se região equivalente, em microscopia eletrônica de varredura. Folha de sol.
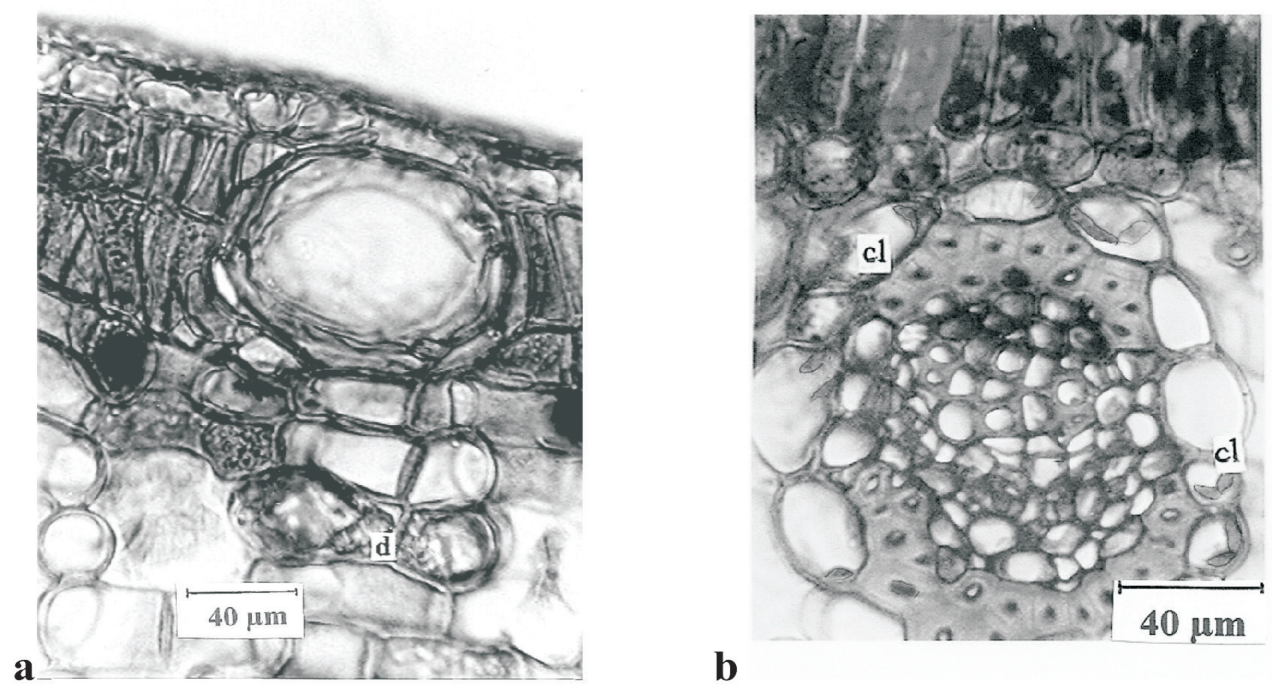

Figura 11. a, Secção transversal da lâmina foliar de Eugenia florida. a, Folha de sol, evidenciando a cavidade secretora intercalada no parênquima paliçádico e drusas de oxalato de cálcio (d) no parênquima lacunoso; b, Folha de sombra, observando-se um feixe vascular colateral, no qual, as células da bainha parenquimática exibem cloroplastos (cl).
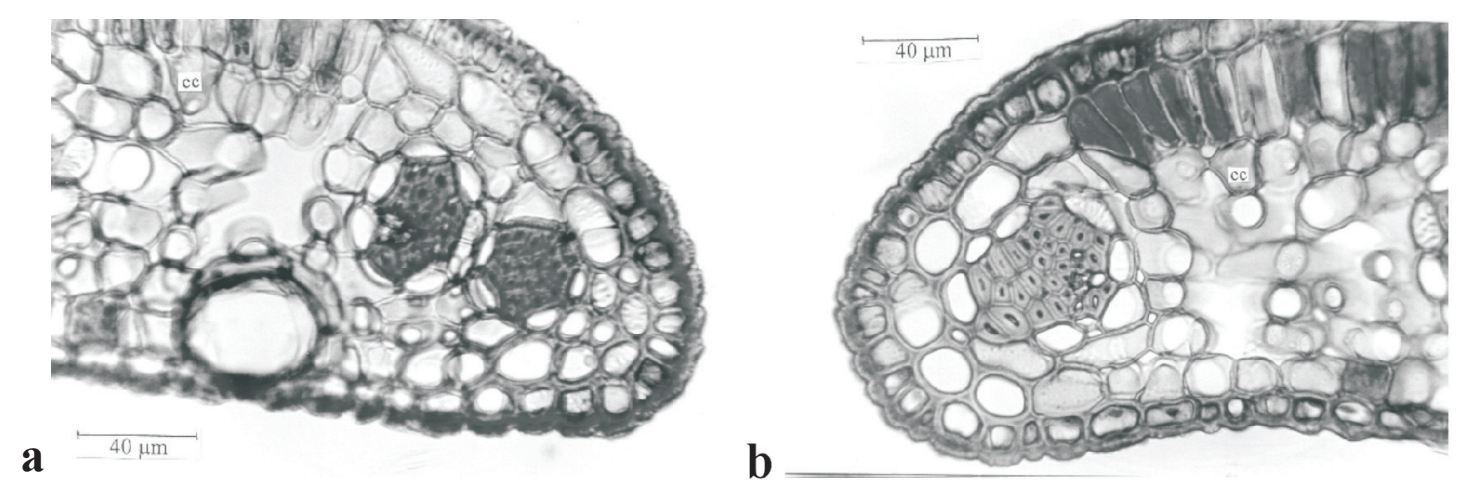

Figura 12. a, Bordo foliar, em secção transversal, de Eugenia florida (folha de sol). Na região distal ocorre um colênquima com espessamento homogêneo, um cordão fibroso e, adjacente a este, um feixe vascular com grande quantidade de fibras. Presença de uma cavidade secretora adjacente à epiderme abaxial; $\mathbf{b}$, Bordo foliar referente à folha de sombra, levemente fletido em direção à face abaxial. Note-se o colênquima menos desenvolvido e a falta do cordão de fibras. cc= célula coletora. 

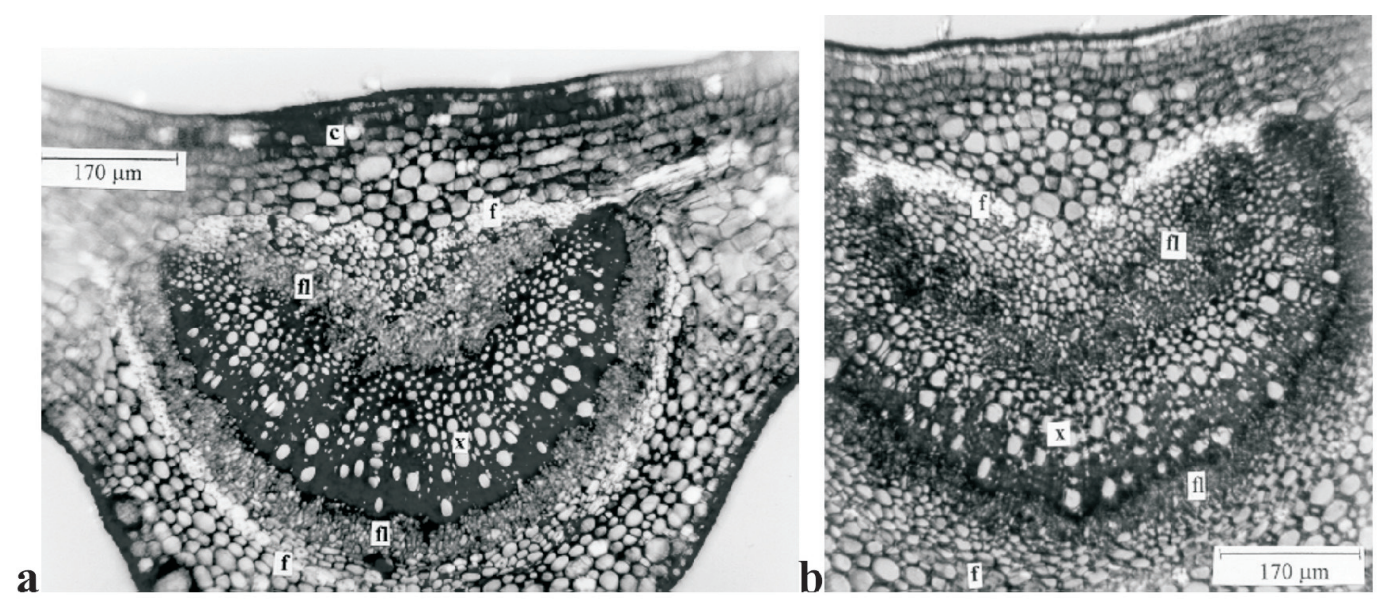

Figura 13. a, Nervura mediana, em secção transversal, de Eugenia florida (folha de sol); b, idem, de folha de sombra; c= cristais; f= fibras; $f$ = floema; $\mathrm{x}=$ xilema.
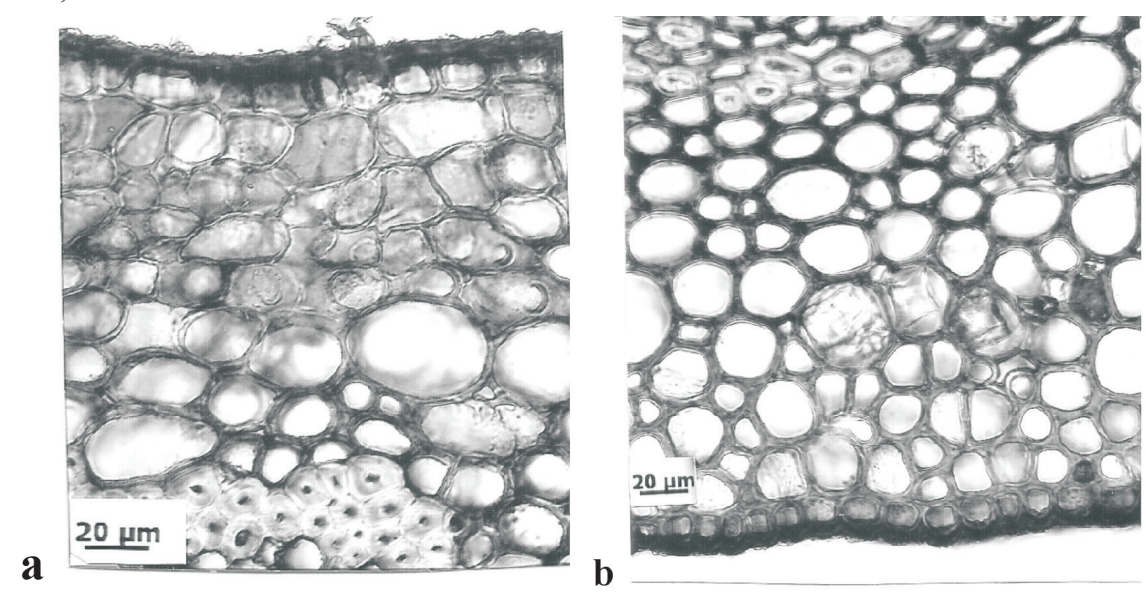

Figura 14. a. Pormenor da região adaxial da nervura mediana, em secção transversal, de Eugenia florida (folha de sol); b, Pormenor da região abaxial da nervura mediana.

Tabela 2. Diferenças anatômicas entre folhas de sol e de sombra de Eugenia florida.

\begin{tabular}{lcc}
\hline & $\begin{array}{c}\text { Folhas de } \\
\text { sol }\end{array}$ & $\begin{array}{c}\text { Folhas de } \\
\text { sombra }\end{array}$ \\
\hline Densidade de estômatos & $\begin{array}{c}392 / \mathrm{mm}^{2} \\
\text { acentuadas }\end{array}$ & $\begin{array}{c}297 / \mathrm{mm}^{2} \\
\text { atenuadas }\end{array}$ \\
Estrias epicuticulares & maior & menor \\
Espessura da cutícula & maior & menor \\
Espessamento das paredes celulares & $240 \mu \mathrm{m}$ & $175 \mu \mathrm{m}$ \\
Espessura da lâmina foliar & dois & um \\
Número de estratos do parênquima & & \\
paliçádico & maior & menor \\
Compactação das células & completa & incompleta \\
Diferenciação das cavidades secretoras & maior & menor \\
Quantidade de cristais & maior & menor \\
Quantidade de cavidades secretoras & maior & menor \\
Quantidade de fibras esclerenquimáticas & maior & menor \\
Lignificação e anisotropia das paredes & & \\
celulares & maior & menor \\
Concentração de compostos ergásticos & maior & menor \\
Densidade vascular & retilíneo & fletido \\
Bordo foliar & &
\end{tabular}

\section{Pecíolo}

A secção transversal da região mediana do pecíolo apresenta-se côncava na região adaxial e convexa na abaxial (Figura 16). A epiderme é uniestratificada, com tricomas simples, tectores, unicelulares, na face adaxial e não apresenta estômatos. A região cortical é constituída por um parênquima com aspecto colenquimatoso, devido à espessura de suas paredes celulares. $\mathrm{Na}$ periferia as células encontram-se mais compactadas e, em posição subepidérmica, ocorrem cavidades secretoras semelhantes às descritas para a lâmina foliar (Figuras 15a, 16). Na região adaxial do pecíolo, o córtex apresenta cerca de dezesseis estratos de células e na região abaxial, há, aproximadamente, vinte camadas celulares. Numerosos idioblastos contendo cristais também são visíveis na região cortical (Figura 15b). A porção central do pecíolo é constituída pelo sistema vascular, organizado em um feixe, em forma de arco com a abertura voltada para a face adaxial (Figuras 15a, 16). A organização do sistema vascular é semelhante ao observado na nervura mediana, porém as margens do arco vascular são mais involutas no pecíolo (Figuras 15a, 16). Guarnecendo o floema localizado adaxialmente, 
ocorrem fibras, cujas paredes mostram-se lignificadas. As demais fibras que circundam o sistema vascular têm as paredes celulósicas. Nos testes histoquímicos constatou-se a presença de uma bainha amilífera perivascular. Grãos de amido foram detectados, também, em algumas células do parênquima cortical e na epiderme. Gotículas de lipídios ocorrem nas cavidades secretoras e em algumas células adjcentes à epiderme. Glicídeos estão presentes em todo o pecíolo, principalmente nas células parenquimáticas próximas ao sistema vascular e nas células dos raios parenquimáticos do floema. As células da epiderme, do parênquima cortical, principalmente as que circundam o sistema vascular, apresentam conteúdo tanífero. Igual situação é observada nas células dos raios parenquimáticos. A região distal do pecíolo apresenta duas pequenas projeções no lado adaxial, ocorrendo, em cada uma, de 1 a 3 pequenos feixes vasculares (Figura 16). As fibras perivasculares apresentam maior grau de lignificação, em comparação com as outras regiões do pecíolo. O restante da organização anatômica é semelhante à descrita para a região mediana. Comparando-se pecíolos provenientes de folhas de sol e de sombra, constata-se, nos primeiros, maior grau de anisotropia e de quantidade de cristais.
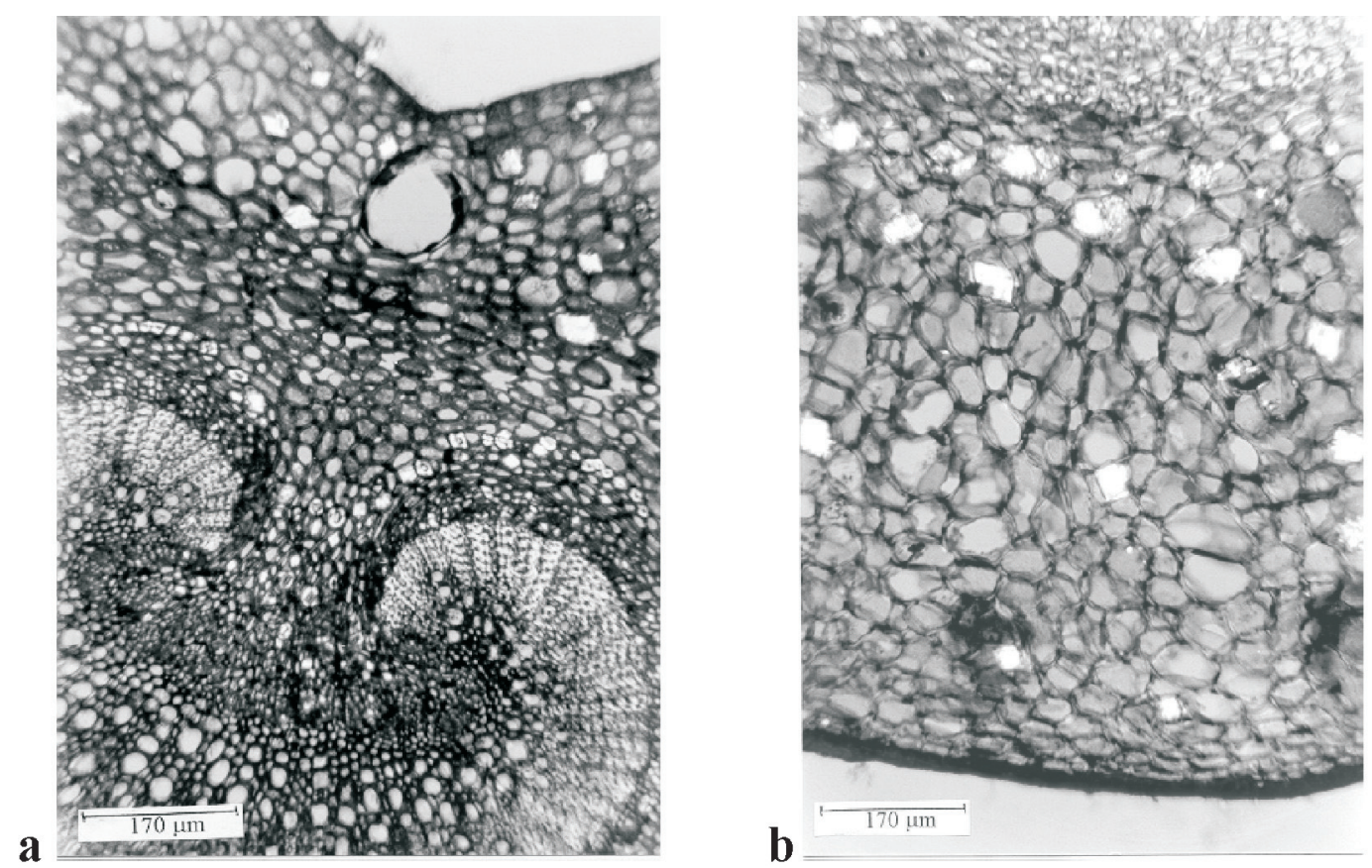

Figura 15. a, Secção transversal da região mediana do pecíolo de Eugenia florida, em luz polarizada, evidenciando parte do sistema vascular e da região cortical adaxial. Próximo à epiderme, visualiza-se uma cavidade secretora; $\mathbf{b}$, Pormenor da região cortical abaxial do pecíolo.
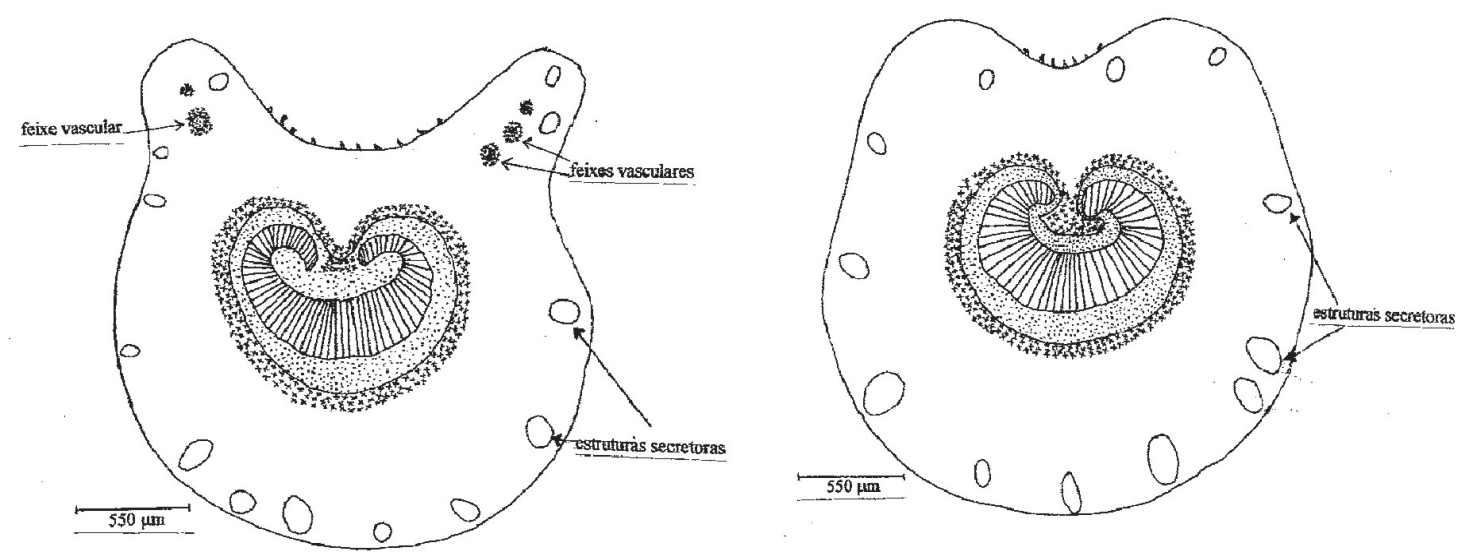

$\square$ parênquima; 圈 fibras; 葛 floema; 㽗 xilema

Figura 16. Esquemas das secções transversais do pecíolo de Eugenia florida, em suas regiões distal (à esquerda) e mediana. Na face adaxial ocorrem tricomas tectores simples. 


\section{DISCUSSÃO}

Os dados morfológicos e anatômicos da folha de $E$. florida reúnem características comuns à família Myrtaceae, podendo-se destacar algumas de importância diagnóstica para a espécie. Como características da família, citam-se: a ocorrência de cavidades secretoras, a presença de floema interno ao xilema e alto teor de tanino (Solereder, 1908; Metcalfe \& Chalk, 1950). Cronquist (1981) acrescenta, ainda, a ocorrência de proantocianinas nas Myrtaceae. Todas essas características foram constatadas no material estudado. A presença de antocianinas em E. florida é restrita às folhas jovens, as quais exibem coloração vinácea. Cronquist (1.c.) menciona, ainda, a presença de uma nervura intramarginal contínua nas folhas dessa família, o que foi confirmado na espécie estudada.

Uma característica de valor diagnóstico para E. florida encontra-se no seu sistema de revestimento, particularmente, nas células epidérmicas situadas sobre as cavidades secretoras de óleos essenciais. Estas são constituídas por uma célula reniforme, rodeada pelas adjacentes, dispostas de forma radiada. A célula de topo reniforme, ao contrário das demais células epidérmicas, permanece incolor, exceto na região da reentrância. Muitas espécies de Myrtaceae já foram analisadas, anatomicamente, constatando-se que as células de cobertura das estruturas secretoras são constituídas, geralmente, por pares de células, cuja parede mediana mostra-se sinuosa. Entre os exemplos desse tipo, citam-se Eugenia nitida (Pereira, 1985), Eugenia uniflora (Neves \& Donato, 1989; Jorge, 1992), Campomanesia xantohocarpa, Myrciaria cauliflora, Psidium cattleyanum, Psidium guajava (Jorge, 1992), Syzygium cumini (Santos, 1994) e Psidium widgrenianum (Donato \& Morretes, 2005). Menos freqüente, é a situação em que ocorre uma única célula de topo, cuja morfologia, em vista frontal, varia entre poligonal, elíptica ou arredondada, com as células adjacentes dispostas radiadamente, como o que se observa em Myrcia multiflora, Plinia edulis (Donato, 2003) e em Eugenia brasiliensis (Donato, 2003; Donato \& Morretes, 2007). Uma única célula de topo com morfologia reniforme, como o que ocorre em E. florida, não foi registrado, até o momento, em outra espécie de Myrtaceae, constituindo-se, dessa forma, numa característica diferencial referente às células de cobertura das cavidades secretoras.

Outras características anatômicas relevantes para a diagnose da espécie incluem a cutícula estriada, a ondulação das paredes anticlinais da epiderme, a ocorrência de numerosos cristais prismáticos encontrados no parênquima paliçádico e o pecíolo, cujo sistema vascular forma um arco com as margens acentuadamente involutas.

As células epidérmicas de $E$. florida apresentam suas paredes periclinais externas espessadas de modo irregular, formando ondulações voltadas para o lume celular. Vários registros dessa característica anatômica foram encontrados na literatura, entre os quais, um referese à família Anacardiaceae (Morretes, 1967), e os restantes, referem-se a espécies da família Myrtaceae. Machado et al (1988) encontraram projeções parietais na epiderme de Eugenia sulcata. Arruda \& Fontenelle (1994) registraram essa característica em Psidium cattleyanum e Fontenelle et. al. (1994) verificaram o mesmo em várias espécies de Eugenia. Gomes (1992) refere o mesmo para duas espécies de Gomidesia. Barros (1998) encontrou estruturas semelhantes em Plinia martinelli e Callado (1993/97), em Eugenia cuprea e Marlieria suaveolens. O significado funcional dessas projeções parietais ainda precisa ser investigado. É fato que, as células que apresentam essa característica, têm a superfície de suas membranas plasmáticas também ampliadas, o que deve ser levado em conta, nas possíveis hipóteses sobre a funcionalidade dessa característica anatômica. Evert (2006) refere que quanto maior for a superfície do sistema "parede-membrana", maior o fluxo de substâncias que a célula pode realizar.

E. florida apresenta o mesofilo tipicamente dorsiventral, compatível com o ambiente nem muito seco nem muito úmido em que ela vive. Eschrich (1995) menciona a presença de células coletoras em folhas que possuem parênquima paliçádico denso, o que foi confirmado em E. florida, a qual apresenta um estrato de células coletoras entre o parênquima paliçádico e o lacunoso.

$\mathrm{Na}$ espécie em estudo constatou-se que as folhas mais expostas ao sol, apresentam maior densidade de vascularização, comparadas às folhas mais sombreadas. Essa característica vem de encontro à observação feita por Eschrich (1.c.), de que os órgãos foliares melhor vascularizados, tornam-se mais aptos a enfrentarem deficiências hídricas. Segundo Metcalfe; Chalk (1988), em muitos taxa, as aréolas apresentam terminações de nervuras, as quais terminam cegamente no mesofilo em íntima associação com as células clorenquimáticas e, em outros, não aparecem nervuras no interior das aréolas. $\mathrm{Na}$ espécie aqui analisada, verifica-se que a vascularização da lâmina foliar enquadra-se no primeiro caso, constatandose que nenhuma célula do mesofilo fica muito distante do suprimento vascular. Eschich (1.c) lembra que as calotas de fibras que ocorrem junto ao floema e ao xilema dos feixes vasculares podem ou não sofrer lignificação, sendo essas duas situações observadas no material estudado.

Esau (1977) afirma que os pecíolos das folhas das dicotiledôneas apresentam grande variedade na organização do sistema vascular. Na espécie aqui estudada verifica-se que o xilema e o floema formam um arco ao longo de todo o pecíolo, prolongando-se por todo o eixo da lâmina foliar, praticamente sem variações.

Em E. florida verifica-se que as fibras perivasculares situadas nas porções proximal e mediana do pecíolo, permanecem com suas paredes celulósicas, sem lignificação. Apenas na porção distal do pecíolo, as fibras localizadas adaxialmente, apresentam as paredes 
lignificadas. Tal fato pode estar relacionado à necessidade de acomodações na posição da lâmina foliar, realizada através de torções do pecíolo, especialmente em sua porção basal. $\mathrm{Na}$ espécie analisada, freqüentemente, o pecíolo apresenta-se torcido na região proximal, o que indica ter havido mudança no posicionamento da lâmina foliar.

Uma das características marcantes do mesofilo das Myrtaceae é a ocorrência de cavidades secretoras subepidérmicas, distribuídas pelas duas faces da lâmina foliar. O seu conteúdo é, essencialmente, lipídico. Em E. florida constatou-se que, nas folhas desenvolvidas na sombra, essas estruturas secretoras têm seu desenvolvimento incompleto, observando-se, nas áreas onde elas ocorrem, um grande espaço delimitado por células, porém sem as características de um epitélio secretor. As folhas de sol, ao contrário, apresentam as cavidades secretoras completamente diferenciadas, com secreção em seu interior e em maior quantidade do que a das folhas de sombra. Os óleos essenciais fazem parte de importante arsenal químico das plantas, podendo atrair agentes polinizadores ou, às vezes, repelir insetos por ação inseticida e dissuasiva alimentar, reduzindo, assim, a herbivoria (Castro; Machado, 2003). Outro fator a ser considerado é que os óleos essenciais têm importante participação nos efeitos terapêuticos das plantas que os produzem e, dessa forma, evidencia-se a conveniência de selecionar folhas com boa exposição à luminosidade, quando a intenção é a sua utilização para fins medicinais.

\section{AGRADECIMENTOS}

Ao Departamento de Botânica do Instituto de Biologia da USP pela utilização do microscópio eletrônico de varredura e suporte laboratorial.

\section{REFERÊNCIAS}

Agra MF, França PF, Barbosa-Filho JM 2007. Synopsis of the plants known as medicinal and poisonous in Northeast of Brazil. Rev Bras Farmacogn 17: 114-140.

Agra MF, Silva KN, Basílio IJLD, França PF, Barbosa-Filho JM 2008. Survey of medicinal plants used in the region Northeast of Brazil. Rev Bras Farmacogn 18: 472-508.

Apel MA, Sobral M, Henriques AT 2006. Composição química do óleo volátil de Myrcianthes nativas da região sul do Brasil. Rev Bras Farmacogn 16: 402-407.

Araújo DSD, Henriques RPG 1984. Análise florística das restingas do Estado do Rio de Janeiro. In: Lacerda LD de, Cerqueira R, Turcq S. Restingas, Origem, Estrutura, Processos. p.159-193, CEUFF, Niterói, Brasil.

Arruda RCO, Fontenelle GB 1994. Contribuição ao estudo da anatomia foliar de Psidum cattleyanum Sabine (Myrtaceae). Rev Bras Bot 17: 25-35.

Barros CF 1998. Estudo da epiderme foliar de espécies tropicais. Rio de Janeiro, 175 p. Tese de Doutorado, Instituto de Biofísica Carlos Chagas Filho, Centro de Ciências da
Saúde, Universidade Federal do Rio de Janeiro.

Barroso GM, Guimarães EF, Ichaso CF, Costa CG, Peixoto AL, Lima HC 1984. Sistemática de Angiospermas do Brasil. $\mathrm{V}$ 2. Viçosa: Imprensa Universitária da Universidade Federal de Viçosa.

Barroso GM, Peron MV 1994. Myrtaceae. In: Lima MPM, Guedes-Bruni RR (orgs.) Reserva Ecológica de Macaé de Cima - Nova Friburgo - RJ. Aspectos Florísticos das Espécies Vasculares. V 1. Rio de Janeiro: Jardim Botânico do Rio de Janeiro, p.261-302.

Bukatsch F 1972. Bemerkungen zur doppelfarbung astrablausafranin. Mikrokosmos 61: 225.

Callado CH 1993/1997. Anatomia foliar de Eugenia cuprea (Berg.) NDZ e Marlieria suaveolens Gard. (Myrtaceae). Rodriguesia 45/49: 25-37.

Carpano SM, Castro MT, Spegazzini ED 2009. Caracterización morfoanatómica comparativa entre Aloe vera (L.) Burm. F., Aloe arborescens Mill., Aloe saponaria Haw. y Aloe ciliaris Haw. (Aloeaceae). Rev Bras Farmacogn 19: 269275.

Castro MM, Machado SR 2003. Células e tecidos secretores. In: Appezzato-da-Glória B, Carmello-Guerreiro SM (eds). Anatomia Vegetal. Viçosa: Universidade Federal de Viçosa, p.179-203.

Castro HG, Ferreira FA, Silva DJH, Mosquim PR 2004. Contribuição ao estudo das plantas medicinais: metabólitos secundários. Viçosa, MG.

Cronquist A 1981. An integrated system of classification of flowering plants. New York: Columbia Univ. Press.

Donato AM 2003. Myrtaceae: Anatomia foliar de cinco espécies nativas com potencial medicinal elou econômico. São Paulo, 199 p. Tese de Doutorado. Instituto de Biociências, Universidade de São Paulo.

Donato AM, Morretes BL 2005. Estudo anatômico das folhas de Psidium widgrenianum Berg. (Myrtaceae), uma potencial espécie medicinal. Rev Bras Farm 86: 65-70.

Donato AM, Morretes BL 2007. Anatomia foliar de Eugenia brasiliensis Lam. (Myrtaceae) proveniente de áreas de restinga e de floresta. Rev Bras Farmacogn 17: 426-443.

Duarte MR, Menarim DO 2006. Morfodiagnose da anatomia foliar e caulinar de Camellia sinensis (L.) Kuntze, Theaceae. Rev Bras Farmacogn 16: 545-551.

Esau K 1977. Anatomy of Seed Plants. New York: John Wiley and Sons.

Eschrich W 1995. Funktionelle Pflanzenantomie. Berlin: Springer-Verlag.

Evert R F 2006. Esau's Plant Anatomy. New Jersey: John Wiley and Sons.

Fontenelle GB, Costa CG, Machado RD 1994. Foliar anatomy and micromorphology of eleven species of Eugenia L. (Myrtaceae). Bot J Linn Soc 115: 111-133.

Foster AS 1949. Practical Plant Anatomy. Princeton: D. van Nostrand Company.

Gomes DMS 1992. Anatomia foliar de Gomidesia spectabilis (DC) Berg. e Gomidesia nitida (Vell.) Legr. Myrtaceae. Rio de Janeiro. Dissertação de Mestrado, Museu 
Nacional, Universidade Federal do Rio de Janeiro.

Gomes RSDL, Oliveira VC, Jácome RLRP, Pinto JEBP, Lameira OA, Barros AMD 2009. Estudo morfoanatômico comparativo entre a poaia (Psychotria ipecacuanha (Brot.) Stokes - Rubiaceae) obtida da região Amazônica (habitat original) e proveniente de processo biotecnológico submetida a diferentes tratamentos de interceptação da radiação solar. Rev Bras Farmacogn 19: 276-283.

Hickey LJ 1979. A revised classification of the architecture of dicotyledonous leaves. In: Metcalfe CR, Chalk L (Ed.). Anatomy of the Dicotyledons. $2^{\text {nd }}$ ed. Oxford: Clarendon Press.

Howarth W, Warne LGG 1959. Practical Botany for the Tropics. London: University of London Press.

Johansen D 1940. Plant Microtechnique. New York: McGraw Hill Book Co.

Jorge LIF 1992. Caracterização farmacobotânica e microscopia alimentar de seis espécies brasileiras de Myrtaceae Jussieu. São Paulo, 140 p. Dissertação de Mestrado. Faculdade de Ciências Farmacêuticas, Universidade de São Paulo.

Junges MJ, Fernandes JB, Vieira PC, Fernandes GS, RFilho E, Frühauf M, Barañano AG 1999. Triterpênicos ursânicos e oleanânicos isolados do caule de Eugenia florida DC. III Reunião da Sociedade Latino-Americana de Fitoquímica. UFRGS, Faculdade de Farmácia.

Leitão F, Fonseca-Kruel VS, Silva IM, Reinert F 2009. Urban ethnobotany in Petrópolis and Nova Friburgo (Rio de Janeiro, Brazil). Rev Bras Farmacogn 19: 333-342.

Leite JPV, Pimenta DS, Gomes RSDL, Dantas-Barros AM 2007. Contribuição ao estudo farmacobotânico da Echinodorus macrophyllus (Kunth) Micheli (chapéu-de-couro) Alismataceae. Rev Bras Farmacogn 17: 242-248.

Machado RD, Costa CG, Fontenelle GB 1988. Anatomia foliar de Eugenia sulcata Spring ex Mart (Myrtaceae). Acata Bot Bras 1 (Supl.): 275-285.

Marques LC, Pieri C, Roman-Júnior WA, Cardoso MLC, Milaneze-Gutierre MA, Mello JCP 2007. Controle farmacognóstico das raízes de Heteropteris aphrodisiaca O. Mach. (Malpighiaceae). Rev Bras Farmacogn 17: 604-615.

Mauro C, Silva CP, Missima J, Ohnuki T, Rinaldi RB, Frota M 2008. Estudo anatômico comparado de órgãos vegetativos de boldo miúdo, Plectranthus ornatus Codd. e malvariço, Plectranthus amboinicus (Lour.) Spreng. - Lamiaceae. Rev Bras Farmacogn 18: 608-613.

McLean RC, Ivemey-Cook WR 1958. Plant Sience Formulae. $2^{\text {nd }}$ ed. London: Macmillan \& Co.

Menezes-de-Lima Jr O, Rosas EC, Henriques MGMO, Branquinho LF, Ramos MFS, Siani AC 1997. Avaliação da atividade antiinflamatória de óleos essenciais de espécies de Myrtaceae e Compositae. III Jornada Paulista de Plantas Medicinais. CPQBA-UNICAMP. Campinas, Brasil.

Metcalfe CR, Chalk L 1950. Anatomy of the Dicotyledons. V 1. Oxford: Clarendon Press.
Metcalfe CR, Chalk R 1988. Anatomy of the Dicotyledons. V 1. Oxford: Clarendon Press.

Mori AS, Boom BM, Carvalino AM, Santos TS 1983. Ecological Importance of Myrtaceae in na Eastern Brazilian Wet Forest. Biotropica 15: 68-70.

Morretes BL 1967. Contribuição ao estudo da anatomia das folhas de plantas do cerrado. II. Bol Fac Fil Cien Letras USP 22: 207-244.

Neves LJ, Donato AM 1989. Contribuição ao estudo de Eugenia uniflora L. (Myrtaceae). Bradea 5: 275-284.

Oliveira F, Akissue G 1989. Fundamentos de Farmacobotânica. Rio de Janeiro, São Paulo: Atheneu Ed.

Pereira AMC 1985. Anatomia foliar de Eugenia nitida Camb. (Myrtaceae). Rio de Janeiro. Dissertação de Mestrado, Museu Nacional, Universidade Federal do Rio de Janeiro.

Santos RE 1994. Anatomia foliar de Syzygium cumini (L.) Skeels (Myrtaceae). Monografia de Bacaharelado, Instituto de Biologia, Universidade do Estado do Rio de Janeiro.

Scopel M, Nunes E, Vignoli-Silva M, Vendruscolo GS, Henriques AT, Mentz LA 2007. Caracterização farmacobotânica das espécies de Sambucus (Caprifoliaceae) utilizadas como medicinais no Brasil. Parte I. Sambucus nigra L. Rev Bras Farmacogn 17: 249-261.

Siani AC, Branquinho LF 1997. Extração e análise química de óleos essenciais de espécies de Myrtaceae. V Reunião de Iniciação Científica da Fundação Oswaldo Cruz. Rio de Janeiro, Brasil.

Siani AC, Ramos MF de S, Silva AMP, Jesus AL 1998a. Ácidos triterpênicos e óleo essencial de duas espécies de Eugenia (Myrtaceae). 21 ${ }^{a}$ Reunião Anual da Sociedade Brasileira de Química. 25 a 28 de maio de 1998. Poços de Caldas. MG, Brasil.

Siani AC, Ramos MF de S, Rodrigues CM, Leite JP 1998 b. Atividade biológica de espécies da família Myrtaceae como agentes inibidores de rotavirus e astrovirus envolvidos na diarréia aguda. I Bienal de Pesquisa. Fundação Oswaldo Cruz. Rio de Janeiro, Brasil.

Solereder H 1908. Sistematic Anatomy of the Dicotyledons. V 1. Oxford: Clarendon Press.

Veiga-Junior VF 2008. Estudo do consumo de plantas medicinais na Região Centro-Norte do Estado do Rio de Janeiro: aceitação pelos profissionais de saúde e modo de uso pela população. Rev Bras Farmacogn 18: 308-313.

Vieira S 1983. Introdução à Bioestatística. $2^{\mathrm{a}}$ ed. Rio de Janeiro: Ed. Campus. 